\title{
Asymmetric Entry into $10 b$-aza-Analogues of Amaryllidaceae Alkaloids Reveals a Pronounced Electronic Effect on Antiviral Activity
}

\author{
Carla E. Brown, ${ }^{\dagger}$ Tiffany Kong, $^{\dagger}$ James F. Britten, $^{\dagger}$ Nick H. Werstiuk, ${ }^{\dagger}$ James McNulty, ${ }^{*}{ }^{\dagger} \odot$
} Leonardo D’Aiuto, ${ }^{\ddagger}$ Matthew Demers, ${ }^{\ddagger}$ and Vishwajit L. Nimgaonkar ${ }^{\ddagger}$

${ }^{\dagger}$ Department of Chemistry \& Chemical Biology, McMaster University, 1280 Main Street West, Hamilton, Ontario L8S 4M1, Canada

${ }^{\ddagger}$ Department of Psychiatry, University of Pittsburgh School of Medicine, 3811 O’Hara Street, Pittsburgh, Pennsylvania 15213, United States

\section{Supporting Information}

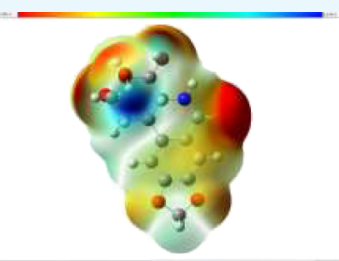

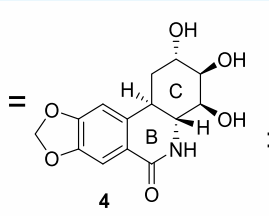

Potent anti HSV-1 activity

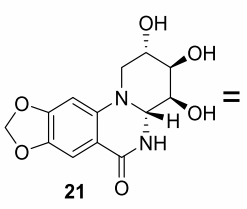

NO HSV-1 activity

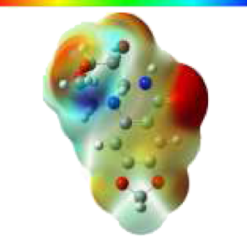

ABSTRACT: Development of a chiral pool-based synthesis of $10 b$-aza-analogues of biologically active Amaryllidaceae alkaloids is described, involving a concise reductive amination and condensation sequence, leading to ring-B/C-modified, fully functionalized ring- $C$ derivatives. Differentiated anticancer and antiviral activities of these analogues are presented. Despite complete conformational and functional group overlap, the $10 b$-aza-analogues have diminished anticancer activity and no antiviral activity. These unprecedented electronic effects suggest a possible role for $\pi$-type secondary orbital interactions with the biological target.

\section{INTRODUCTION}

Amaryllidaceae alkaloids have attracted the attention of medicinal $^{1-4}$ and synthetic organic chemists $^{5-8}$ for many decades in view of the diverse array of biological activities demonstrated. Examples include (Figure 1A) galanthamine (1) used clinically in the treatment of Alzheimer's disease, ${ }^{9}$ the anticancer agent pancratistatin (2), ${ }^{10}$ and the selective anticancer/antiviral agents trans-dihydronarciclasine $(3)^{11,12}$
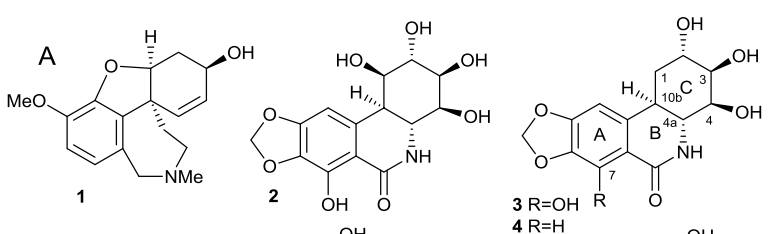

$\mathrm{OH}$
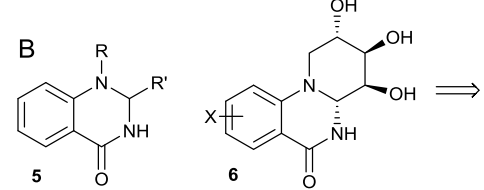

$4 \mathrm{R}=\mathrm{H}$

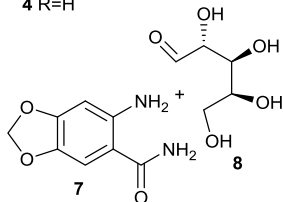

Figure 1. (A) Structure of representative Amaryllidaceae constituents galanthamine (1), pancratistatin (2), trans-dihydronarciclasine (3), and trans-dihydrolycoricidine (4) and (B) general quinazolidinone core structure (5), the novel hybrid heterocycle 6 and proposed retrosynthesis from an anthranilamide 7 , and pentose L-arabinose $(8)$. and trans-dihydrolycoricidine (4). ${ }^{13}$ The latter two alkaloids have recently been reported to exhibit potent activity against Zika virus, ${ }^{12}$ herpes simplex virus type 1 (HSV-1), and varicella zoster virus. $^{13}$

Despite the common structural motifs apparent in compounds 1-4, these biological activities manifest through diverse mechanisms. Galanthamine is a potent inhibitor of acetylcholinesterase, ${ }^{14}$ whereas pancratistatin selectively targets cancer cell mitochondria. ${ }^{15}$ The antiviral profile is unusual with potent activity being reported against both DNA and RNA viruses, ${ }^{11-13}$ and accordingly several antiviral targets have been postulated. ${ }^{16,17}$ Significant efforts have been made to elucidate the anticancer pharmacophore of pancratistatin. This work has revealed that ring-A substituents and the stereochemistry of ring-C substituents are crucial for activity, ${ }^{18-22}$ leading to the identification of analogues that are more potent than the natural products. ${ }^{23,24}$ The ring-A 7-aza-analogue proved to be devoid of anticancer activity, ${ }^{25}$ while the 10 -aza-analogue was potent, ${ }^{26}$ demonstrating the importance of the evaluation of aza analogues in revealing the subtle electronic requirements of the pharmacophore. The contribution of structural modifications on the antiviral activity is also critical ${ }^{13}$ but much less

Received: August 10, 2018

Accepted: September 6, 2018

Published: September 20, 2018 
Scheme 1. L-Arabinose (8) Selectively Protected at C5 Alcohol as TBS-Ether Was Coupled to Anthranilamide (7b) via a Reductive Amination: (a) TBS-Cl, Pyridine; (b) $\mathrm{NaCNBH}_{3}, \mathrm{MeOH}_{\text {; }}$ and (c) $\mathrm{Ac}_{2} \mathrm{O}$, DIPEA, DCM

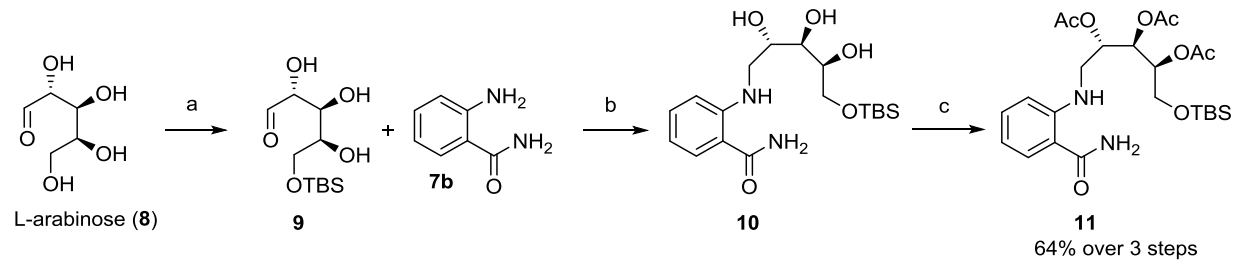

Scheme 2. Conversion of 11 via Deprotection, Oxidation, and Ring Closure to the Quinazolinone-Lycorane Hybrids 15 and 16: (d) HF•Py, THF; (e) IBX, DMSO, $60{ }^{\circ} \mathrm{C}$; and (f) $\mathrm{K}_{2} \mathrm{CO}_{3}, \mathrm{MeOH}$; Bottom: ORTEP Diagram of 14<smiles>CC(=O)OC1CN2c3ccccc3C(=O)NC2C(OC(C)=O)C(OC(C)=O)C1OC(C)=O</smiles><smiles>CC(=O)OC1CN2c3ccccc3C(=O)NC2C(OC(C)=O)C1OC(C)=O</smiles><smiles>O=C1OC23CCN(OC(C(=O)N2)C(O)C3O)c2ccccc21</smiles><smiles>CC(=O)OC1CN2c3ccccc3C(=O)NC2C(OC(C)=O)C1OC(C)=O</smiles><smiles>O=C1NC2C(O)C(O)C(O)CN2c2ccccc21</smiles>

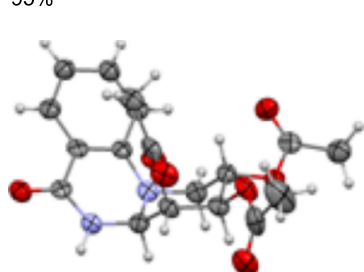

established. ${ }^{11-13}$ Only a single report on the structure-activity relationship of ring-B modified lycoranes (dengue virus) has appeared. $^{27}$

The potent, selective antiviral activity of a series of quinazolinone derivatives (Figure 1, 5) was recently reported against HSV $-1 .^{28,30}$ These compounds are accessible via a onepot multicomponent coupling reaction of an amine, an aldehyde, and an anthranilamide derivative. High selectivity was observed for anti-HSV-1 activity in neuronal host cells for both compound 4 and the quinazolinones. ${ }^{13,26}$ Given the synthetic challenges associated with the synthesis of fully functionalized alkaloids such as 3 and $4,^{5-8,12,29}$ we have now explored a new hybrid quinazolinone-lycorane heterocyclic core shown as structure 6 (Figure 1). We envisioned that compounds such as 6 could be elaborated in an asymmetric fashion from an anthranilamide such as 7 and a chiral-pool pentose (such as 8) in a few steps. In this communication, we report the success of this route and rapid synthesis of the compound of structural type 6 , including 21 which is the $10 b$ aza-analogue of the potent antiviral agent trans-dihydrolycoricidine (4), from L-arabinose in six steps (carried out in four chemical procedures) with a $23 \%$ overall yield.

\section{RESULTS AND DISCUSSION}

Two initial attempts to fuse pentoses such as D-ribose and Larabinose onto anthranilamide $\mathbf{7 b}$ through $\mathrm{N}$-alkylation of the protected 5-iodo analogues failed due to chemoselectivity incompatibilities, and we eventually settled on the process outlined in Schemes 1-3. The C5 primary alcohol of Larabinose, possessing the desired stereochemistry, was selectively protected as the TBS-ether 9 (Scheme 1), which, due to its hydrophilicity, was immediately engaged in the reductive amination with anthranilamide $7 \mathbf{b}$ in the same reaction vessel affording intermediate $\mathbf{1 0}$. After a short solvent partition sequence, the crude triol $\mathbf{1 0}$ was acylated to give $\mathbf{1 1}$, which was isolated and purified over silica. The overall threestage telescoped reaction sequence was highly efficient giving access to 11 with $64 \%$ overall yield (based on L-arabinose) over three steps, requiring only a single silica-gel chromatographic purification.

Removal of the TBS-protecting group in $\mathbf{1 1}$ employing tetrabutylammonium fluoride in THF gave the primary alcohol 12 contaminated with products of acetyl migration, attributed to these basic conditions. Conversely, the use of HF.pyridine complex in THF resulted in clean deprotection with no acyl transfer, and the desired primary alcohol 12 was isolated in high yield (Scheme 2). The selective oxidation of the primary alcohol to the aldehyde proved more challenging than expected and a number of different conditions were investigated. An attempted Swern oxidation unexpectedly resulted in dehydration of the amide in $\mathbf{1 2}$ leading to the nitrile derivative, while an attempted oxidation under Parikh-Doering conditions failed completely, and no conversion of the starting material was observed. Reaction of 12 using Dess-Martin periodinane resulted in rapid decomposition of the starting 
Scheme 3. Synthesis of 21 and 22 from L-Arabinose (8) and 3,4-Methylenedioxyanthranilamide (7a): (a) TBS-Cl, Pyridine; (b) $\mathrm{NaCNBH}_{3}, \mathrm{MeOH}$; (c) $\mathrm{Ac}_{2} \mathrm{O}$, DIPEA, DCM; (d) HF•Py, THF; (e) IBX, DMSO, $60{ }^{\circ} \mathrm{C}$; and (f) $\mathrm{K}_{2} \mathrm{CO}_{3}, \mathrm{MeOH}^{\circ}$<smiles>O=CC(O)C(O)O</smiles>

8

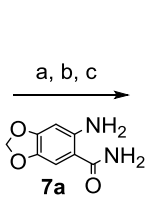

$7 a \mathrm{O}$<smiles></smiles>

$68 \%$ over 3 steps<smiles>CCOC(CNc1cc2c(cc1C(N)=O)OCO2)C(O)OC(=O)O</smiles>

$92 \%$<smiles>CCCCCCCCCCOC(C)=O</smiles><smiles>CC(=O)OC1CN2c3cc4c(cc3C(=O)N[C@H]2[C@H]1OC(C)=O)OCO4</smiles>

$46 \%$<smiles>CC(=O)OC1[C@@H](OC(C)=O)[C@H](OC(C)=O)[C@@H]2CN1c1cc3c(cc1C(=O)N2)OCO3</smiles>

19

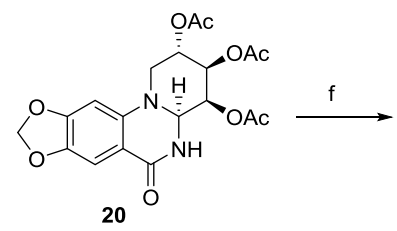

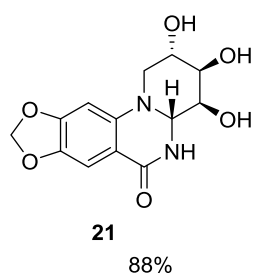<smiles>O=C1NC2[C@H](O)[C@H](O)[C@@H](O)CN2c2cc3c(cc21)OCO3</smiles>

material. Finally, oxidation with IBX in dimethyl sulfoxide (DMSO) at $60{ }^{\circ} \mathrm{C}$ was found to proceed selectively, the intermediate aldehyde immediately condensing as expected, ${ }^{28}$ to give the desired fused-ring products 13 and $\mathbf{1 4}$ as a 1:2 mixture of separable diastereomers. Saponification of each of the separated diastereomers with $\mathrm{K}_{2} \mathrm{CO}_{3}$ in $\mathrm{MeOH}$ afforded the desired individual triols 15 and 16 completing the synthesis of these new hybrid model compounds. We also determined that, separately, 13 and 14 do not interconvert under the cyclization conditions, indicating them to be the products of a kinetically controlled intramolecular condensation.

A single crystal X-ray structural analysis of the major diastereomer 14 was conducted, confirming the overall course of the chemistry as anticipated and confirming the stereochemistry of the major diastereomer as shown in Scheme 2. Interestingly, the $10 b$-aza heterocycle 14 was seen to adopt the alternative chair conformer as normally observed in the carbocyclic natural series. The C2- and C3-acetoxy and 4aamino substituents of $\mathbf{1 4}$ adopt equatorial positions while the C4-acetoxy group projects axially. Diastereomer 14 crystallized as the thermodynamically more stable one of its chair conformers. A crystal structure of diastereomer 13 or deacetylated product 15 could not be obtained; however, the ${ }^{1} \mathrm{H}$ NMR spectra of 15 is consistent $(\mathrm{H} 4 a, \delta 4.59, \mathrm{~d}, J=9.0$ $\mathrm{Hz}$ ) with the adoption of the natural phenanthridone-type chair conformer, having equatorial C4-hydroxyl and $4 a$-amino and diaxial C2, C3 alcohols. Thus, the diastereomeric pairs 13/ 14 or $15 / 16$ adopt radically different three-dimensional projections of the crucial ring-C substituents with diastereomers 13 and 15 (and 19 and 21 vide infra) matching those of biologically active compounds such as 4 .

The synthetic route was now repeated with the 3,4methylenedioxy-substituted anthranilamide 7a (Scheme 3), essentially as before. The three-step telescoped intermediate 17 was isolated in a highly efficient $68 \%$ yield. Desilylation of 17 and IBX-mediated oxidation of 18 gave two ring-fused diastereomers 19 and 20 in a ratio of 3:4 (by mass). These diastereomers also proved readily separable over the silica gel, and each compound was independently saponified yielding the methylenedioxy-substituted quinazolidinone-lycorane hybrids 21 and 22. The chiral pool strategy thus allowed rapid, convergent fusion of L-arabinose onto the substituted anthranilamides giving access to $\mathbf{2 1}$, the direct $10 b$-azaanalogue (Figure 1, 6) of trans-dihydrolycoricidine, and analogues 13, 14, 15, 16, 19, 20, 21, and 22 (see Scheme 3).

Preliminary anticancer investigations have been carried out on compound 4 and select $10 b$-aza-analogues. As the ring- $\mathrm{A}$ methylenedioxy substituent and free ring-C hydroxyl substituents are the known required features for anticancer activity, $^{11}$ the antiproliferative activity of compound $\mathbf{4}$ and the two hydroxyl derivatives $\mathbf{2 1}$ and $\mathbf{2 2}$ was investigated in four hematopoietic cancer cell lines. Compound 21 retained selective anticancer activity toward Karpas422 (9.72 $\mu \mathrm{M})$, Toledo $(18.9 \mu \mathrm{M})$, and $\mathrm{K562}(13.23 \mu \mathrm{M})$ but was inactive toward MV4-11 cell lines. As expected, the synthetic compound 4 demonstrated potent broad-spectrum activity to Karpas422 (0.076 $\mu \mathrm{M})$, Toledo $(0.061 \mu \mathrm{M})$, and K562 (0.076 
$\mu \mathrm{M})$ and to the MV4-11 $(0.073 \mu \mathrm{M})$ cell lines. The diastereomer 22 proved to be devoid of anticancer activity in all four cell lines investigated.

Preliminary anti-HSV-1 activity of select compounds has also been investigated with sharply defined results. As shown in Figure 2, neurons infected with HSV-1 were cultured at $2 \mathrm{~h}$

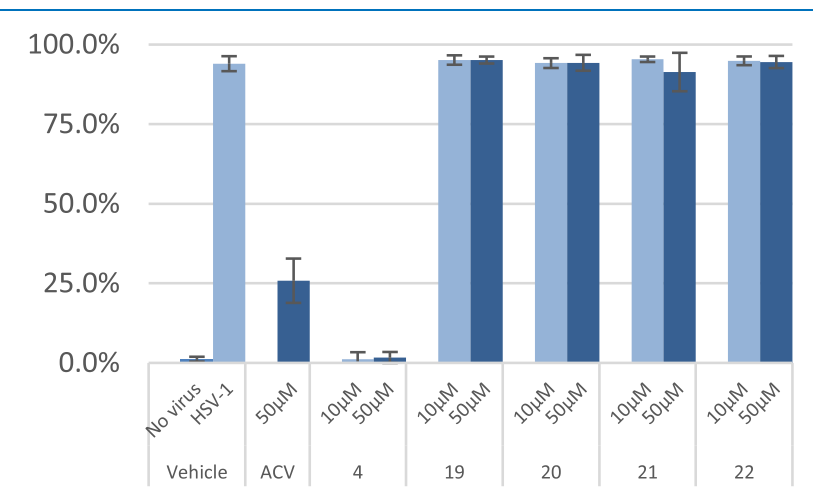

Figure 2. Anti-HSV-1 activity of synthetic compounds 4 and 19-22 in neurons infected with HSV-1 expressing EGFP linked to the ICP90 promoter at $\mathrm{MOI}=0.3 ; Y$-axis depicts GFP+ cell percentage. Vehicle $=$ uninfected and viral-infected untreated cells and $\mathrm{ACV}=$ acyclovirpositive control.

post infection and were treated with test compounds. While the synthetic alkaloid 4 proved to be a potent inhibitor of HSV-1 replication as expected, ${ }^{13}$ the hybrid $10 b$-aza derivatives 19, 20, 21, and 22 demonstrated no inhibition of HSV-1. ${ }^{28}$ The introduction of the $10 b$-aza nitrogen in 21 was not expected to change the ring- $\mathrm{C}$ conformation of the molecule significantly in comparison to 4; however, the introduced dipole in 21 (vinylogous amide) was expected to affect the electronic properties. Given the sharp differences observed in the anti-HSV-1 activity of the compounds 4 and 21, a detailed conformational analysis was conducted in an attempt to separate the electronic effects from the conformational/ functional group attributes.

In addition to the X-ray analysis of diastereomer 14 (see 14, Scheme 2), further evidence in support of the conformations was obtained through investigation of density functional theory (DFT) calculations on compounds 4, 21, and 22, the calculated minima of which are depicted in Figure 3 (see Supporting Information). Compounds 4 and 21 adopt the natural phenanthridone-type chair conformation in ring-C, whereas the aza-diastereomer $\mathbf{2 2}$ alone adopts the alternative conformer, identical to that observed in the X-ray structure of compound 14. The antiviral and anticancer results thus correlate with the adoption of the biased phenanthridonetype chair conformation as a critical conformational requirement. The differences in anti-HSV-1 activity seen between compounds 4 (cyclohexane) and 21 (vinylogous amide) are remarkable, given the structural overlap seen. This work demonstrates that substitution of the $10 \mathrm{~b}$ carbon with nitrogen is not tolerated for antiviral activity and that the natural phenanthridone-type ring-C conformation is required for potent anticancer activity and is crucial for antiviral activity. The structure-activity dichotomy between structures $\mathbf{4}$ and $\mathbf{2 1}$ is quite startling. Molecular electrostatic potential heat maps (see graphical abstract) show that $\mathbf{4}$ has an electropositive hole over ring-C, and aza-analogue $\mathbf{2 1}$ is less electropositive over
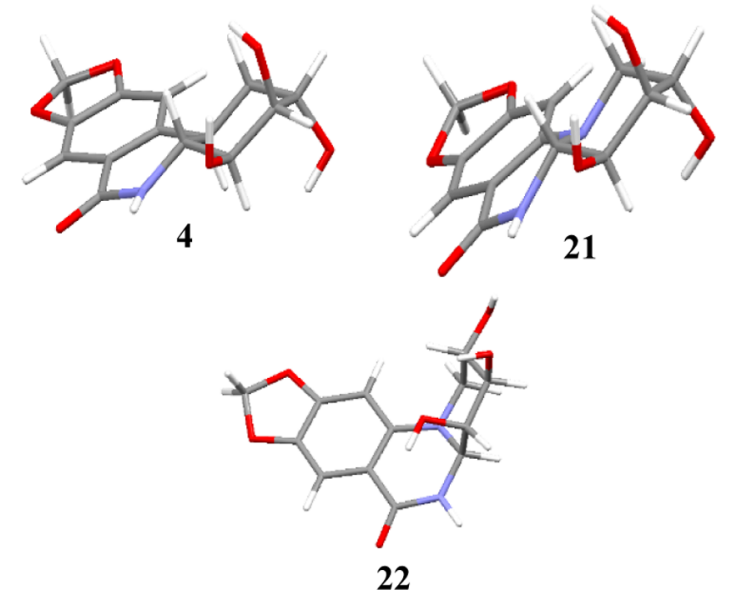

Figure 3. DFT-optimized molecular geometry (B3PW91/6-311+G$(2 \mathrm{~d}, \mathrm{p})$ ) of compounds 4 (top left) and 21 (top right) illustrating identical ring-C phenanthridone-type conformations in contrast with diastereomer 22 (bottom).

this surface, highlighting a possible role of $\pi$-type secondary orbital interactions with the antiviral target.

Position $10 b$ in these derivatives is the only position that may potentially affect the electrostatic potential of rings $A, B$, and C. The data show little effect on rings $A$ and $B$, but a significant reduction in electron density in ring-C. The data draw attention to the different electronic distributions within the highest occupied molecular orbitals and lowest unoccupied molecular orbitals (see Supporting Information Figures S1S3) of $\mathbf{4}$ and $\mathbf{2 1}$ as the only differences, suggesting increasing electron density toward position $10 b$ as a method by which selective anticancer agents can be developed. The critical role of electronic properties (not conformational) of ring-C in analogue $\mathbf{4}$ for potent antiviral activity is unprecedented.

\section{CONCLUSIONS}

In conclusion, we report a rapid six-step (four processes) convergent route to quinazolinone-Amaryllidaceae alkaloid hybrid molecules. The use of readily available chiral pool pentoses allows absolute control of three stereogenic centers and minimizes the number of stereoselective reactions required to produce the functionally dense core. Although there are several reports in the literature describing the antiviral and anticancer pharmacophore of Amaryllidaceae analogues, there are few reports of B/C-ring fusion-modified derivatives. The selective anticancer and antiviral activities reported here highlight the requirement of a correct ring-C (natural phenanthridone-type) chair conformation and reveal the unprecedented subtle role of electrostatic interactions required for antiviral activity and potent anticancer activity. Further studies exploring electronic modifications of fully functionalized analogues and their selective broad-spectrum antiviral and anticancer activities are ongoing.

\section{EXPERIMENTAL SECTION}

All reagents were obtained from MilliporeSigma and used as received unless otherwise specified. THF was distilled over sodium metal with a benzophenone indicator. Dichloromethane, methanol, and diisopropylethylamine were distilled over calcium hydride for use in reactions performed under anhydrous conditions. Reagent grade methanol, diethyl ether, dichloromethane, ethyl acetate, and hexane were used without 
further purification and for chromatography. Thin layer chromatography (TLC) was performed using aluminum sheets precoated with silica gel $60 \mathrm{~F}_{254}$ (MACHEREY-NAGEL) and visualized using $254 \mathrm{~nm}$ UV light. ${ }^{1} \mathrm{H}$ and ${ }^{13} \mathrm{C}$ NMR spectra were recorded on a Bruker AV 600 spectrometer using $\mathrm{CDCl}_{3}$ or $d_{4}-\mathrm{MeOH}$ as solvents. Chemical shifts $(\delta)$ are reported in ppm and coupling constants $(J)$ are expressed in hertz.

4.1. $(2 S, 3 R, 4 S)-1-(($ tert-Butyldimethylsilyl)oxy)-5-((2carbamoylphenyl)amino)pentane-2,3,4-triyl Triacetate (11). A round-bottom flask was charged with L-arabinose (150 mg, $1.00 \mathrm{mmol}, 1$ equiv) and pyridine $(1.20 \mathrm{~mL}, 15.0$ mmol, 15 equiv). To this suspension, $t$-butyldimethylsilylchloride (163 mg, $1.05 \mathrm{mmol}, 1.05$ equiv) was added in portions. This reaction mixture was stirred at room temperature for $2 \mathrm{~h}$ and then concentrated to a total volume of 0.5 $\mathrm{mL}$ to afford protected sugar 9. A solution of anthranilamide (130 mg, $0.95 \mathrm{mmol}, 0.95$ equiv) in dry methanol $(1.0 \mathrm{~mL})$ was added to the flask. After $10 \mathrm{~min}, \mathrm{NaCNBH}_{3}(120 \mathrm{mg}, 1.91$ mmol, 1.9 equiv) was added. Upon completion of the reaction as determined by TLC (typically 5-10 $\mathrm{min}$ ), water was added to quench the reaction mixture. This aqueous solution was extracted with dichloromethane $(3 \times 15 \mathrm{~mL})$. The combined organic phase was dried over sodium sulphate and concentrated to dryness under reduced pressure to afford the crude product 10, which contained an inseparable sugar impurity. In a round-bottom flask, crude $\mathbf{1 0}$ was dissolved in dry dichloromethane $(3.3 \mathrm{~mL})$ to which were added diisopropylethylamine $(1.7 \mathrm{~mL}, 9.9 \mathrm{mmol}, 10$ equiv), acetic anhydride (566 $\mu \mathrm{L}, 6.0 \mathrm{mmol}, 6$ equiv), and $N, N$-dimethylaminopyridine ( $6.0 \mathrm{mg}, 0.05 \mathrm{mmol}, 0.05$ equiv). This reaction mixture was stirred for $3 \mathrm{~h}$ at room temperature, and then quenched by the addition of water. This aqueous solution was extracted with dichloromethane $(3 \times 15 \mathrm{~mL})$. The combined organic phase was dried over sodium sulphate and concentrated to dryness under reduced pressure. This material was then purified by gradient elution silica-gel chromatography (80:20 hexane/ EtOAc $\rightarrow$ 30:70 hexane/EtOAc) to afford 11 as a yellow oil in a $64 \%$ isolated yield over the three-step sequence. ${ }^{1} \mathrm{H}$ NMR $\left(600 \mathrm{MHz}, \mathrm{CDCl}_{3}\right): \delta 7.44(\mathrm{dd}, J=7.9,1.5 \mathrm{~Hz}, 1 \mathrm{H}), 7.36$ (ddd, $J=8.6,7.2,1.6 \mathrm{~Hz}, 1 \mathrm{H}), 6.93(\mathrm{~d}, J=8.4 \mathrm{~Hz}, 1 \mathrm{H}), 6.70$ $(\mathrm{t}, J=7.5 \mathrm{~Hz}, 1 \mathrm{H}), 5.43(\mathrm{dd}, J=8.4,2.4 \mathrm{~Hz}, 1 \mathrm{H}), 5.38$ (ddd, $J$ $=8.1,5.8,2.4 \mathrm{~Hz}, 1 \mathrm{H}), 5.07(\mathrm{ddd}, J=8.3,5.0,3.2 \mathrm{~Hz}, 1 \mathrm{H})$, $3.73(\mathrm{dd}, J=11.5,3.2 \mathrm{~Hz}, 1 \mathrm{H}), 3.66(\mathrm{dd}, J=11.5,5.0 \mathrm{~Hz}$, $1 \mathrm{H}), 3.39-3.31(\mathrm{~m}, 2 \mathrm{H}), 2.13(\mathrm{~s}, 3 \mathrm{H}), 2.09(\mathrm{~s}, 3 \mathrm{H}), 2.01(\mathrm{~s}$, $3 \mathrm{H}), 0.85$ (s, 9H), $0.01(\mathrm{~s}, 3 \mathrm{H}),-0.00(\mathrm{~s}, 3 \mathrm{H}) ;{ }^{13} \mathrm{C} \mathrm{NMR}$ $\left(151 \mathrm{MHz}, \mathrm{CDCl}_{3}\right): \delta 171.54,170.75,170.16,170.02,134.70$, $133.81,128.56,116.96,113.51,108.00,71.01,69.66,68.76$, $61.82,60.55,44.35,25.85,21.10,20.96,20.89,18.33,-5.42$. ESI HRMS: calcd for $\mathrm{C}_{24} \mathrm{H}_{38} \mathrm{~N}_{2} \mathrm{O}_{8} \mathrm{Si}[\mathrm{M}+\mathrm{H}]^{+}$, 511.2470; found, 511.2470; $[\alpha]_{\mathrm{D}}^{20}+14.4^{\circ}\left(\mathrm{CHCl}_{3}, c 0.016\right)$.

4.2. (2S,3R,4S)-1-((2-Carbamoylphenyl)amino)-5-hydroxypentane-2,3,4-triyl Triacetate (12). Compound 11 ( $107 \mathrm{mg}, 0.20 \mathrm{mmol}, 1.0$ equiv) was dissolved in dry THF (3.2 $\mathrm{mL})$ to which were added $\mathrm{HF}-$ pyridine $(274 \mu \mathrm{L})$. This reaction mixture was stirred for $1 \mathrm{~h}$ at room temperature and then quenched by the addition of solid $\mathrm{NaHCO}_{3}$. After $15 \mathrm{~min}$, water and dichloromethane were added to form an aqueousorganic partition. The aqueous was extracted exhaustively with dichloromethane and then the combined organic phases were dried with sodium sulphate and concentrated to dryness. This afforded 12 as a pale yellow oil in $92 \%$ yield, which was used immediately in the next transformation.
4.3. $(2 S, 3 R, 4 S, 4 a R)-6-0 \times 0-2,3,4,4 a, 5,6-$ hexahydro- $1 H$ pyrido[1,2-a]quinazoline-2,3,4-triyl Triacetate (13). 2Iodoxybenzoic acid (12 mg, $0.043 \mathrm{mmol}, 1.2$ equiv) was dissolved in reagent grade DMSO $(100 \mu \mathrm{L})$ and heated to 60 ${ }^{\circ} \mathrm{C}$ for $30 \mathrm{~min}$. A solution of compound $12(15 \mathrm{mg}, 0.036$ mmol, 1.0 equiv) in DMSO $(100 \mu \mathrm{L})$ was then added. This reaction mixture was stirred for $15 \mathrm{~min}$ at $60{ }^{\circ} \mathrm{C}$ and then purified directly by silica gel chromatography (100:0 $\mathrm{Et}_{2} \mathrm{O} /$ EtOAc $\rightarrow$ 90:10 $\mathrm{Et}_{2} \mathrm{O} / \mathrm{EtOAc}$ ) to afford 13 and 14 as a $1: 2$ mixture of diastereomers in $36 \%$ yield. 13 was obtained as a clear, colorless oil; ${ }^{1} \mathrm{H}$ NMR $\left(600 \mathrm{MHz}, \mathrm{CDCl}_{3}\right): \delta 7.95$ (dd, $J$ $=7.7,1.7 \mathrm{~Hz}, 1 \mathrm{H}), 7.40$ (ddd, $J=8.7,7.3,1.7 \mathrm{~Hz}, 1 \mathrm{H}), 6.92$ $(\mathrm{td}, J=7.5,0.9 \mathrm{~Hz}, 1 \mathrm{H}), 6.83(\mathrm{~s}, 1 \mathrm{H}), 6.75(\mathrm{~d}, J=8.4 \mathrm{~Hz}$, $1 \mathrm{H}), 5.49-5.45(\mathrm{~m}, 1 \mathrm{H}), 5.29$ (dd, $J=9.5,3.0 \mathrm{~Hz}, 1 \mathrm{H}), 5.03$ $(\mathrm{dt}, J=4.1,2.1 \mathrm{~Hz}, 1 \mathrm{H}), 4.95(\mathrm{dd}, J=9.6,1.9 \mathrm{~Hz}, 1 \mathrm{H}), 4.06$ (dd, $J=14.5,1.9 \mathrm{~Hz}, 1 \mathrm{H}), 3.26(\mathrm{dd}, J=14.5,2.1 \mathrm{~Hz}, 1 \mathrm{H})$, 2.99 (s, 1H), $2.14(\mathrm{~s}, 3 \mathrm{H}), 2.10(\mathrm{~s}, 3 \mathrm{H}), 2.06(\mathrm{~s}, 3 \mathrm{H}) ;{ }^{13} \mathrm{C}$ NMR (151 MHz, $\left.\mathrm{CDCl}_{3}\right): \delta 170.10,169.92,169.21,163.68$, $147.93,134.33,129.18,119.78,116.41,112.17,69.67,68.01$, $67.09,65.93,44.03,21.19,20.94,20.88$. ESI HRMS: calcd for $\mathrm{C}_{18} \mathrm{H}_{20} \mathrm{~N}_{2} \mathrm{O}_{7}[\mathrm{M}+\mathrm{H}]^{+}$, 377.1343; found, 377.1342; $[\alpha]_{\mathrm{D}}^{20}$ $+69.9^{\circ}\left(\mathrm{CHCl}_{3}, \mathrm{c} 0.0029\right)$.

4.4. (2S,3R,4S,4aS)-6-Oxo-2,3,4,4a,5,6-hexahydro-1Hpyrido[1,2-a]quinazoline-2,3,4-triyl Triacetate (14). Colorless solid. ${ }^{1} \mathrm{H}$ NMR $\left(600 \mathrm{MHz}, \mathrm{CDCl}_{3}\right): \delta 7.93$ (dd, $J=7.8$, $1.7 \mathrm{~Hz}, 1 \mathrm{H}), 7.45$ (ddd, $J=8.3,7.4,1.7 \mathrm{~Hz}, 1 \mathrm{H}), 6.95-6.87$ $(\mathrm{m}, 2 \mathrm{H}), 6.31(\mathrm{~s}, 1 \mathrm{H}), 5.46(\mathrm{dd}, J=3.2,1.7 \mathrm{~Hz}, 1 \mathrm{H}), 5.22(\mathrm{td}$, $J=10.3,4.9 \mathrm{~Hz}, 1 \mathrm{H}), 5.11(\mathrm{dd}, J=10.2,3.2 \mathrm{~Hz}, 1 \mathrm{H}), 4.92$ (dd, $J=2.5,1.7 \mathrm{~Hz}, 1 \mathrm{H}), 4.26$ (dd, $J=13.4,5.0 \mathrm{~Hz}, 1 \mathrm{H}), 2.76$ (dd, $J=13.4,10.5 \mathrm{~Hz}, 1 \mathrm{H}), 2.13(\mathrm{~s}, 3 \mathrm{H}), 2.02$ (s, 3H), 1.89 (s, $3 \mathrm{H}) ;{ }^{13} \mathrm{C}$ NMR $\left(151 \mathrm{MHz}, \mathrm{CDCl}_{3}\right): \delta 170.47,170.45,170.10$, $163.48,147.10,134.82,128.70,119.85,116.42$, 111.79, 70.90, 68.79, 65.64, 53.57, 46.01, 21.05, 20.79, 20.55. ESI HRMS: calcd for $\mathrm{C}_{18} \mathrm{H}_{20} \mathrm{~N}_{2} \mathrm{O}_{7}[\mathrm{M}+\mathrm{H}]^{+}, 377.1343$; found, 377.1344; $[\alpha]_{\mathrm{D}}^{20}+77.2^{\circ}\left(\mathrm{CHCl}_{3}, c 0.0067\right)$. A small sample suitable for $\mathrm{X}$ ray diffraction was crystallized from hexanes/EtOAc (50:50) by slow evaporation in the refrigerator.

4.5. $(2 S, 3 R, 4 S, 4 a R)-2,3,4-T r i h y d r o x y-1,2,3,4,4 a, 5$-hexahydro-6H-pyrido[1,2-a]quinazolin-6-one (15). Compound 13 (3.5 mg, $0.01 \mathrm{mmol}, 1.0$ equiv) and $\mathrm{K}_{2} \mathrm{CO}_{3}(0.6$ $\mathrm{mg}, 0.005 \mathrm{mmol}, 0.5$ equiv) were dissolved in a $3: 1$ mixture of methanol/water $(100 \mu \mathrm{L})$. After $30 \mathrm{~min}$, this mixture was purified directly by silica gel chromatography (100:0 DCM/ $\mathrm{MeOH} \rightarrow 80: 20 \mathrm{DCM} / \mathrm{MeOH})$ to afford 15 as a white, amorphous solid in $92 \%$ yield. ${ }^{1} \mathrm{H}$ NMR $(600 \mathrm{MHz}$, methanol$\left.d_{4}\right): \delta 7.81(\mathrm{dd}, J=7.7,1.7 \mathrm{~Hz}, 1 \mathrm{H}), 7.43(\mathrm{ddd}, J=8.8,7.2,1.7$ $\mathrm{Hz}, 1 \mathrm{H}), 6.98(\mathrm{~d}, J=8.4 \mathrm{~Hz}, 1 \mathrm{H}), 6.89-6.85(\mathrm{~m}, 1 \mathrm{H}), 4.59$ $(\mathrm{d}, J=9.0 \mathrm{~Hz}, 1 \mathrm{H}), 4.02-3.98(\mathrm{~m}, 2 \mathrm{H}), 3.95(\mathrm{t}, J=3.5 \mathrm{~Hz}$, $1 \mathrm{H}), 3.70$ (dd, $J=13.0,2.4 \mathrm{~Hz}, 1 \mathrm{H}), 3.13(\mathrm{dd}, J=13.0,2.3$ $\mathrm{Hz}, 1 \mathrm{H}) ;{ }^{13} \mathrm{C}$ NMR $\left(151 \mathrm{MHz}\right.$, methanol- $\left.d_{4}\right): \delta 166.49$, $151.39,135.48,129.12,119.89,117.76,113.87,71.61,70.29$, 69.77, 68.93, 46.82; $[\alpha]_{\mathrm{D}}^{20}+116.9^{\circ}(\mathrm{MeOH}, c 0.00092)$.

4.6. $(2 S, 3 R, 4 S, 4 a S)-2,3,4-T r i h y d r o x y-1,2,3,4,4 a, 5-h e x-$ ahydro-6H-pyrido[1,2-a]quinazolin-6-one (16). Compound 14 ( $8.0 \mathrm{mg}, 0.02 \mathrm{mmol}, 1.0$ equiv) and $\mathrm{K}_{2} \mathrm{CO}_{3}(1.5$ $\mathrm{mg}, 0.011 \mathrm{mmol}, 0.5$ equiv) were dissolved in a $3: 1$ mixture of methanol/water $(200 \mu \mathrm{L})$. After $30 \mathrm{~min}$, this mixture was purified directly by silica gel chromatography (100:0 DCM/ $\mathrm{MeOH} \rightarrow 80: 20 \mathrm{DCM} / \mathrm{MeOH})$ to afford 16 as a white, amorphous solid in $95 \%$ yield. ${ }^{1} \mathrm{H}$ NMR $(600 \mathrm{MHz}$, methanol$\left.d_{4}\right): \delta 7.76(\mathrm{dd}, J=7.7,1.7 \mathrm{~Hz}, 1 \mathrm{H}), 7.39$ (ddd, $J=8.4,7.3,1.7$ $\mathrm{Hz}, 1 \mathrm{H}), 6.90(\mathrm{~d}, J=8.3 \mathrm{~Hz}, 1 \mathrm{H}), 6.80(\mathrm{td}, J=7.5,0.9 \mathrm{~Hz}$, $1 \mathrm{H}), 4.65(\mathrm{~d}, J=1.7 \mathrm{~Hz}, 1 \mathrm{H}), 3.97(\mathrm{dd}, J=12.7,5.2 \mathrm{~Hz}, 1 \mathrm{H})$, 
$3.93-3.88(\mathrm{~m}, 2 \mathrm{H}), 3.42(\mathrm{dd}, J=9.4,3.1 \mathrm{~Hz}, 1 \mathrm{H}), 2.53(\mathrm{dd}, J$ $=12.7,10.6 \mathrm{~Hz}, 1 \mathrm{H}) ;{ }^{13} \mathrm{C}$ NMR $\left(151 \mathrm{MHz}\right.$, methanol- $\left.d_{4}\right): \delta$ $166.57,150.30,135.46,128.99,119.25,117.31,112.64,75.47$, 73.27, 71.57, 66.80, 49.85; $[\alpha]_{\mathrm{D}}^{20}-129.0^{\circ}(\mathrm{MeOH}, c 0.0038)$.

4.7. $(2 S, 3 R, 4 S)-1-(($ tert-Butyldimethylsilyl)oxy)-5-((6carbamoylbenzo[d][1,3]dioxol-5-yl)amino)pentane2,3,4-triyl Triacetate (17). A round-bottom flask was charged with L-arabinose (50 $\mathrm{mg}, 0.35 \mathrm{mmol}, 1$ equiv) and pyridine ( $400 \mu \mathrm{L}, 15 \mathrm{mmol}, 15$ equiv). To this suspension, $t$ butyldimethylsilylchloride ( $54 \mathrm{mg}, 0.36 \mathrm{mmol}, 1.05$ equiv) was added in portions. This reaction mixture was stirred at room temperature for $2 \mathrm{~h}$, and then concentrated to a total volume of $0.5 \mathrm{~mL}$. A solution of 3,4-methylenedioxyanthranilamide (60 $\mathrm{mg}, 0.33 \mathrm{mmol}, 0.95$ equiv) in dry methanol $(320 \mu \mathrm{L})$ was added to the flask. After $10 \mathrm{~min}, \mathrm{NaCNBH}_{3}(42 \mathrm{mg}, 0.66$ mmol, 1.9 equiv) was added. Upon completion of the reaction as determined by TLC (typically $2-5 \mathrm{~min}$ ), water was added to quench the reaction mixture. This aqueous solution was extracted with dichloromethane $(3 \times 5 \mathrm{~mL})$. The combined organic phase was dried over sodium sulphate and concentrated to dryness under reduced pressure. This mixture was dissolved in dry dichloromethane $(1.0 \mathrm{~mL})$ to which were added diisopropylethylamine ( $575 \mu \mathrm{L}, 3.3 \mathrm{mmol}, 10$ equiv), acetic anhydride (187 $\mu \mathrm{L}, 1.98 \mathrm{mmol}, 6$ equiv), and $N, N$ dimethylaminopyridine $(2.0 \mathrm{mg}, 0.016 \mathrm{mmol}, 0.05$ equiv $)$. This reaction mixture was stirred for $3 \mathrm{~h}$ at room temperature and then quenched by the addition of water. This aqueous solution was extracted with dichloromethane $(3 \times 15 \mathrm{~mL})$. The combined organic phase was dried over sodium sulphate and concentrated to dryness under reduced pressure. This material was then purified by chromatography (80:20 hexane/ EtOAc $\rightarrow 30: 70$ hexane/EtOAc) to afford 17 as a yellow oil in a $68 \%$ isolated yield over three steps. ${ }^{1} \mathrm{H}$ NMR $(600 \mathrm{MHz}$, $\left.\mathrm{CDCl}_{3}\right): \delta 6.85(\mathrm{~s}, 1 \mathrm{H}), 6.42(\mathrm{~s}, 1 \mathrm{H}), 5.90(\mathrm{~s}, 2 \mathrm{H}), 5.58(\mathrm{~s}$, $2 \mathrm{H}), 5.42(\mathrm{dd}, J=8.4,2.4 \mathrm{~Hz}, 1 \mathrm{H}), 5.33(\mathrm{ddd}, J=7.7,5.5,2.4$ $\mathrm{Hz}, 1 \mathrm{H}), 5.07$ (ddd, $J=8.4,5.0,3.3 \mathrm{~Hz}, 1 \mathrm{H}), 3.73(\mathrm{dd}, J=$ 11.5, $3.2 \mathrm{~Hz}, 1 \mathrm{H}), 3.66(\mathrm{dd}, J=11.4,5.0 \mathrm{~Hz}, 1 \mathrm{H}), 3.33$ (dd, $J$ $=15.4,5.9 \mathrm{~Hz}, 1 \mathrm{H}), 3.25(\mathrm{dd}, J=14.5,7.2 \mathrm{~Hz}, 1 \mathrm{H}), 2.13(\mathrm{~s}$, $3 \mathrm{H}), 2.08(\mathrm{~s}, 3 \mathrm{H}), 2.02(\mathrm{~s}, 3 \mathrm{H}), 0.86(\mathrm{~s}, 9 \mathrm{H}), 0.02(\mathrm{~s}, 3 \mathrm{H})$, $0.01(\mathrm{~s}, 3 \mathrm{H}) ;{ }^{13} \mathrm{C} \mathrm{NMR}\left(151 \mathrm{MHz}, \mathrm{CDCl}_{3}\right): \delta 171.44,170.59$, 170.15, 169.99, 152.60, 147.91, 138.51, 107.12, 105.24, 101.43, $93.95,71.08,69.70,68.89,61.80,44.26,25.86,21.13,20.92$, $20.89,18.33,-5.41$. ESI HRMS: calcd for $\mathrm{C}_{25} \mathrm{H}_{38} \mathrm{~N}_{2} \mathrm{O}_{10} \mathrm{Si}[\mathrm{M}$ $+\mathrm{H}]^{+}, 555.2368$; found, 555.2366; $[\alpha]_{\mathrm{D}}^{20}-8.7^{\circ}\left(\mathrm{CHCl}_{3}, c\right.$ $0.013)$.

4.8. $(2 S, 3 R, 4 S)-1-((6-$ Carbamoylbenzo[ $[d][1,3]$ dioxol-5yl)amino)-5-hydroxypentane-2,3,4-triyl Triacetate (18). Compound 17 (95 mg, $0.17 \mathrm{mmol}, 1.0$ equiv) was dissolved in dry THF $(2.7 \mathrm{~mL})$ to which were added HF-pyridine (233 $\mu \mathrm{L})$. This reaction mixture was stirred for $20-30 \mathrm{~min}$ at room temperature and closely monitored by TLC to avoid the rearrangement of acetate-protecting groups. When the reaction was complete (typically $15-25 \mathrm{~min}$ ), it was quenched by the addition of solid $\mathrm{NaHCO}_{3}$. After $15 \mathrm{~min}$, water and dichloromethane were added to form an aqueous-organic partition. The aqueous was extracted exhaustively with dichloromethane, and then the combined organic phases were dried with sodium sulphate and concentrated to dryness. This afforded $\mathbf{1 8}$ as a pale yellow oil in $95 \%$ yield, which was used immediately in the next transformation.

4.9. $(2 S, 3 R, 4 S, 4 a R)-6-0 \times 0-2,3,4,4 a, 5,6$-hexahydro- $1 H$ [1,3]dioxolo[4,5-g]pyrido[1,2-a]quinazoline-2,3,4-triyl Triacetate (19). 2-Iodoxybenzoic acid (54 mg, $0.20 \mathrm{mmol}, 1.2$ equiv) was dissolved in reagent grade DMSO $(500 \mu \mathrm{L})$ and heated to $60{ }^{\circ} \mathrm{C}$ for $30 \mathrm{~min}$. A solution of compound 18 (72 $\mathrm{mg}, 0.16 \mathrm{mmol}, 1.0$ equiv) in $\mathrm{DMSO}(200 \mu \mathrm{L})$ was then added. This reaction mixture was stirred for $15 \mathrm{~min}$ at $60{ }^{\circ} \mathrm{C}$ and then purified directly by silica gel chromatography (100:0 $\mathrm{Et}_{2} \mathrm{O} / \mathrm{EtOAc} \rightarrow$ 90:10 $\mathrm{Et}_{2} \mathrm{O} / \mathrm{EtOAc}$ ) to afford 19 and 20 as a $3: 4$ mixture of diastereomers in $45 \%$ yield. 19 was obtained as a clear, colorless oil; ${ }^{1} \mathrm{H} \mathrm{NMR}\left(600 \mathrm{MHz}, \mathrm{CDCl}_{3}\right): \delta 7.39$ (s, $1 \mathrm{H}), 6.36(\mathrm{~s}, 1 \mathrm{H}), 6.34(\mathrm{~s}, 1 \mathrm{H}), 5.96(\mathrm{~d}, J=1.2 \mathrm{~Hz}, 1 \mathrm{H}), 5.45$ $(\mathrm{t}, J=3.6 \mathrm{~Hz}, 1 \mathrm{H}), 5.29(\mathrm{dd}, J=9.2,3.1 \mathrm{~Hz}, 1 \mathrm{H}), 5.06-5.04$ $(\mathrm{m}, 1 \mathrm{H}), 4.84(\mathrm{dd}, J=9.2,1.5 \mathrm{~Hz}, 1 \mathrm{H}), 3.84(\mathrm{dd}, J=14.2,2.5$ $\mathrm{Hz}, 1 \mathrm{H}$ ), 3.23 (dd, $J=14.2,2.4 \mathrm{~Hz}, 1 \mathrm{H}), 2.13$ (s, 3H), 2.09 (s, $6 \mathrm{H}) ;{ }^{13} \mathrm{C}$ NMR $\left(151 \mathrm{MHz}, \mathrm{CDCl}_{3}\right): \delta 170.07,169.24,163.56$, $153.24,145.57,141.70,131.05,107.88,101.87,94.62,69.38$, 67.77, 66.94, 66.27, 44.97, 21.14, 20.92, 20.86. ESI HRMS: calcd for $\mathrm{C}_{19} \mathrm{H}_{20} \mathrm{~N}_{2} \mathrm{O}_{9}[\mathrm{M}+\mathrm{H}]^{+}, 420.1169$; found, 420.1238; $[\alpha]_{\mathrm{D}}^{20}-13.4^{\circ}\left(\mathrm{CHCl}_{3}, c 0.0031\right)$.

4.10. (2S,3R,4S,4aS)-6-Oxo-2,3,4,4a,5,6-hexahydro$1 H$-[1,3]dioxolo[4,5-g]pyrido[1,2-a]quinazoline-2,3,4triyl Triacetate (20). Clear, colorless oil. ${ }^{1} \mathrm{H}$ NMR (600 $\mathrm{MHz}_{\mathrm{CDCl}}$ ): $\delta 7.38(\mathrm{~s}, 1 \mathrm{H}), 6.48(\mathrm{~s}, 1 \mathrm{H}), 6.20(\mathrm{~s}, 1 \mathrm{H}), 5.97$ $(\mathrm{d}, J=1.9 \mathrm{~Hz}, 2 \mathrm{H}), 5.46(\mathrm{t}, J=2.7 \mathrm{~Hz}, 1 \mathrm{H}), 5.21(\mathrm{td}, J=9.6$, $4.7 \mathrm{~Hz}, 1 \mathrm{H}), 5.10(\mathrm{dd}, J=9.6,3.3 \mathrm{~Hz}, 1 \mathrm{H}), 4.83(\mathrm{~d}, J=2.2 \mathrm{~Hz}$, $1 \mathrm{H}), 4.01(\mathrm{dd}, J=13.0,4.8 \mathrm{~Hz}, 1 \mathrm{H}), 2.74(\mathrm{dd}, J=13.1,9.6$ $\mathrm{Hz}, 1 \mathrm{H}), 2.13(\mathrm{~s}, 3 \mathrm{H}), 2.04(\mathrm{~s}, 3 \mathrm{H}), 2.01(\mathrm{~s}, 3 \mathrm{H}) ;{ }^{13} \mathrm{C} \mathrm{NMR}$ $\left(151 \mathrm{MHz}, \mathrm{CDCl}_{3}\right): \delta 170.48,170.33,170.05,163.47,153.25$, $144.82,141.96,110.42,107.65,101.86,95.15,70.04,69.74$, 68.62, 66.06, 46.71, 21.04, 20.82, 20.74. ESI HRMS: calcd for $\mathrm{C}_{19} \mathrm{H}_{20} \mathrm{~N}_{2} \mathrm{O}_{9}[\mathrm{M}+\mathrm{H}]^{+}, 420.1169$; found, 420.1247; $[\alpha]_{\mathrm{D}}^{20}$ $+10.0^{\circ}\left(\mathrm{CHCl}_{3}, c 0.094\right)$.

4.11. $(2 S, 3 R, 4 S, 4 a R)-2,3,4-T r i h y d r o x y-1,2,3,4,4 a, 5-$ hexahydro- $6 \mathrm{H}$-[1,3]dioxolo[4,5-g]pyrido[1,2-a]quinazolin-6-one (21). Compound $19(4.7 \mathrm{mg}, 0.011 \mathrm{mmol}$, 1.0 equiv) and $\mathrm{K}_{2} \mathrm{CO}_{3}(0.8 \mathrm{mg}, 0.006 \mathrm{mmol}, 0.5$ equiv) were dissolved in 3:1 mixture of $\mathrm{MeOH} /$ water $(130 \mu \mathrm{L})$. After 30 min, this mixture was purified directly by silica gel chromatography (100:0 DCM/MeOH $\rightarrow$ 80:20 DCM/ $\mathrm{MeOH})$ to afford 21 as a white, amorphous solid in $81 \%$ yield. ${ }^{1} \mathrm{H}$ NMR $\left(600 \mathrm{MHz}\right.$, methanol- $\left.d_{4}\right): \delta 7.24(\mathrm{~s}, 1 \mathrm{H}), 6.63$ (s, 1H), $5.97(\mathrm{~s}, 2 \mathrm{H}), 4.53(\mathrm{~d}, J=8.8 \mathrm{~Hz}, 1 \mathrm{H}), 4.03-3.99(\mathrm{~m}$, $2 \mathrm{H}), 3.94(\mathrm{t}, J=3.6 \mathrm{~Hz}, 1 \mathrm{H}), 3.58(\mathrm{dd}, J=12.9,2.6 \mathrm{~Hz}, 1 \mathrm{H})$, $3.13(\mathrm{dd}, J=12.9,2.3 \mathrm{~Hz}, 1 \mathrm{H}) ;{ }^{13} \mathrm{C} \mathrm{NMR}(151 \mathrm{MHz}$, methanol- $\left.d_{4}\right): \delta 172.42,161.63,156.86,141.98,115.76$, $110.87,104.49,79.50,77.63,77.21,55.91,49.53$. ESI HRMS: calcd for $\mathrm{C}_{13} \mathrm{H}_{14} \mathrm{~N}_{2} \mathrm{O}_{6}[\mathrm{M}+\mathrm{H}]^{+}, 295.0925$; found, 295.0917; $[\alpha]_{\mathrm{D}}{ }^{20}+34.2^{\circ}(\mathrm{MeOH}, c 0.0023)$.

4.12. $(2 S, 3 R, 4 S, 4 a S)-2,3,4-T r i h y d r o x y-1,2,3,4,4 a, 5-$ hexahydro- $6 H$-[ 1,3$]$ dioxolo [4,5-g]pyrido[1,2-a]quinazolin-6-one (22). Compound 20 (12.0 mg, 0.029 mmol, 1.0 equiv) and $\mathrm{K}_{2} \mathrm{CO}_{3}(1.9 \mathrm{mg}, 0.014 \mathrm{mmol}, 0.5$ equiv) were dissolved in a 3:1 mixture of methanol/water $(250 \mu \mathrm{L})$. After $30 \mathrm{~min}$, this mixture was purified directly by silica gel chromatography (100:0 DCM/MeOH $\rightarrow$ 80:20 DCM/ $\mathrm{MeOH})$ to afford 22 as a white, amorphous solid in $88 \%$ yield; ${ }^{1} \mathrm{H}$ NMR (600 MHz, methanol- $\left.d_{4}\right): \delta 7.20(\mathrm{~s}, 1 \mathrm{H}), 6.55$ $(\mathrm{s}, 1 \mathrm{H}), 5.94(\mathrm{~d}, J=1.2 \mathrm{~Hz}, 2 \mathrm{H}), 4.55(\mathrm{~d}, J=1.9 \mathrm{~Hz}, 1 \mathrm{H})$, 3.95-3.91 (m, 2H), $3.82(\mathrm{dd}, J=12.4,5.1 \mathrm{~Hz}, 1 \mathrm{H}), 3.43-3.41$ $(\mathrm{m}, 1 \mathrm{H}), 2.49(\mathrm{dd}, J=12.4,10.4 \mathrm{~Hz}, 1 \mathrm{H}) ;{ }^{13} \mathrm{C}$ NMR $(151$ $\mathrm{MHz}$, methanol- $\left.d_{4}\right): \delta 154.65,148.18,142.19,129.60,128.88$, $107.69,102.96,95.32,75.14,72.39,71.74,67.08,50.65$. ESI HRMS: calcd for $\mathrm{C}_{13} \mathrm{H}_{14} \mathrm{~N}_{2} \mathrm{O}_{6}[\mathrm{M}+\mathrm{H}]^{+}, 295.0925$; found, 295.0917; $[\alpha]_{\mathrm{D}}^{20}+60.2^{\circ}(\mathrm{MeOH}, c 0.0045)$. 


\section{ASSOCIATED CONTENT}

\section{S Supporting Information}

The Supporting Information is available free of charge on the ACS Publications website at DOI: 10.1021/acsomega.8b01987.

Computational methods for the DFT analysis and procedures for the synthesis of aza-alkaloid derivatives and copies of ${ }^{1} \mathrm{H}$ and ${ }^{13} \mathrm{C}$ NMR spectra (PDF)

\section{AUTHOR INFORMATION}

\section{Corresponding Author}

*E-mail: jmcnult@mcmaster.ca (J.M.).

ORCID $\odot$

James McNulty: 0000-0002-7123-7588

\section{Author Contributions}

The manuscript was written through contributions of all authors. All authors have given approval to the final version of the manuscript.

\section{Funding}

This work was supported by NSERC (to J.M.) and the Stanley Medical Research Institute (to J.M. and V.L.N.). C.E.B. is the recipient of a NSERC (Canada) postgraduate fellowship and T.K. of an NSERC undergraduate student research award.

\section{Notes}

The authors declare no competing financial interest.

Crystallographic data for compound $\mathbf{1 4}$ is deposited under CCDC file 1822440 .

\section{ACKNOWLEDGMENTS}

We thank Dr. Richard Marcellus at the Ontario Institute for Cancer Research in Toronto, ON for conducting the anticancer assays. Computing resources of SHARCnet [Shared Hierarchical Academic Research Computing Network (of Ontario)] were used in this study.

\section{REFERENCES}

(1) Jin, Z. Amaryllidaceae and Sceletium Alkaloids. Nat. Prod. Rep. 2013, 30, 849-868.

(2) Bastida, J.; Berkov, S.; Pigni, N. B.; de Andrade, J. P.; Martínez, V.; Codina, C.; Viladomat, F. Chemical and Biological Aspects of Amaryllidaceae Alkaloids. In Recent Advances in Pharmaceutical Sciences; Muñoz-Torrero, D., Ed.; 2011; pp 65-100.

(3) Evidente, A.; Kireev, A.; Jenkins, A.; Romero, A.; Steelant, W.; Van Slambrouck, S.; Kornienko, A. Biological Evaluation of Structurally Diverse Amaryllidaceae Alkaloids and Their Synthetic Derivatives: Discovery of Novel Leads for Anticancer Drug Design. Planta Med. 2009, 75, 501-507.

(4) Martin, S. F. The Amaryllidacea Alkaloids. In The Alkaloids; Brossi, A., Ed.; Cambridge, Mass., 1987; Vol. 30, pp 251-376.

(5) Ghavre, M.; Froese, J.; Pour, M.; Hudlicky, T. Synthesis of Amaryllidaceae Constituents and Unnatural Derivatives. Angew. Chem., Int. Ed. 2016, 55, 5642-5691.

(6) Banwell, M. G.; Gao, N. Y.; Schwartz, B. D.; White, L. V. Synthetic Studies on Amaryllidaceae and Other Terrestrially Derived Alkaloids. Alkaloid Synthesis; Topics in Current Chemistry; Springer Berlin Heidelberg: Berlin, Heidelberg, 2011; Vol. 309, pp 163-202.

(7) Manpadi, M.; Kornienko, A. Total Syntheses of Pancratistatin: A Review. Org. Prep. Proced. Int. 2008, 40, 107-161.

(8) Chapleur, Y.; Chretien, F.; Ibn Ahmed, S.; Khaldi, M. Chemistry and Synthesis of Highly Oxygenated Alkaloids From Amaryllidaceae: Lycoricidine, Narciclasine, Pancratistatin and Analogs. Curr. Org. Synth. 2006, 3, 341-378.
(9) Heinrich, M.; Lee Teoh, H. Galanthamine From Snowdrop-the Development of a Modern Drug Against Alzheimer's Disease From Local Caucasian Knowledge. J. Ethnopharmacol. 2004, 92, 147-162.

(10) Pettit, G. R.; Gaddamidi, V.; Cragg, G. M. Antineoplastic Agents, 105. Zephyranthes Grandiflora. J. Nat. Prod. 1984, 47, 10181020.

(11) Gabrielsen, B.; Monath, T. P.; Huggins, J. W.; Kefauver, D. F.; Pettit, G. R.; Groszek, G.; Hollingshead, M.; Kirsi, J. J.; Shannon, W. M.; Schubert, E. M.; DaRe, J.; Ugarkar, B.; Ussery, M. A.; Phelan, M. J. Antiviral (RNA) Activity of Selected Amaryllidaceae Isoquinoline Constituents and Synthesis of Related Substances. J. Nat. Prod. 1992, 55, 1569-1581.

(12) Revu, O.; Zepeda-Velázquez, C.; Nielsen, A. J.; McNulty, J.; Yolken, R. H.; Jones-Brando, L. Total Synthesis of the Natural Product (+)-Trans-Dihydronarciclasine via an Asymmetric Organocatalytic [3+3]-Cycloaddition and Discovery of Its Potent Anti-Zika Virus (ZIKV) Activity. ChemistrySelect 2016, 1, 5895-5899.

(13) McNulty, J.; D’Aiuto, L.; Zhi, Y.; McClain, L.; ZepedaVelázquez, C.; Ler, S.; Jenkins, H. A.; Yee, M. B.; Piazza, P.; Yolken, R. H.; Kinchington, P. R.; Nimgaonkar, V. L. iPSC Neuronal Assay Identifies Amaryllidaceae Pharmacophore with Multiple Effects Against Herpesvirus Infections. ACS Med. Chem. Lett. 2016, 7, 46-50.

(14) McNulty, J.; Nair, J. J.; Little, J. R. L.; Brennan, J. D.; Bastida, J. Structure-Activity Studies on Acetylcholinesterase Inhibition in the Lycorine Series of Amaryllidaceae Alkaloids. Bioorg. Med. Chem. Lett. 2010, 20, 5290-5294.

(15) Griffin, C.; Karnik, A.; McNulty, J.; Pandey, S. Pancratistatin Selectively Targets Cancer Cell Mitochondria and Reduces Growth of Human Colon Tumor Xenografts. Mol. Cancer Ther. 2011, 10, 57-68.

(16) He, J.; Qi, W.-B.; Wang, L.; Tian, J.; Jiao, P.-R.; Liu, G.-Q.; Ye, W.-C.; Liao, M. Amaryllidaceae Alkaloids Inhibit Nuclear-toCytoplasmic Export of Ribonucleoprotein (RNP) Complex of Highly Pathogenic Avian Influenza Virus H5N1. Influenza Other Respir. Viruses 2013, 7, 922-931.

(17) Zou, G.; Puig-Basagoiti, F.; Zhang, B.; Qing, M.; Chen, L.; Pankiewicz, K. W.; Felczak, K.; Yuan, Z.; Shi, P.-Y. A Single-Amino Acid Substitution in West Nile Virus 2K Peptide Between NS4A and NS4B Confers Resistance to Lycorine, a Flavivirus Inhibitor. Virology 2009, 384, 242-252.

(18) Pettit, G. R.; Pettit, G. R., III; Backhaus, R. A.; Boyd, M. R.; Meerow, A. W. Antineoplastic Agents, 256. Cell Growth Inhibitory Isocarbostyrils From Hymenocallis. J. Nat. Prod. 1993, 56, 16821687.

(19) Rinner, U.; Hillebrenner, H. L.; Adams, D. R.; Hudlicky, T.; Pettit, G. R. Synthesis and Biological Activity of Some Structural Modifications of Pancratistatin. Bioorg. Med. Chem. Lett. 2004, 14, 2911-2915

(20) Nieto-García, O.; Alonso, R. Synthesis and Cytotoxicity of (+/-)-7,9-Dideoxy-Pancratistatin Analogues. Org. Biomol. Chem. 2013, $11,515-522$.

(21) McNulty, J.; Larichev, V.; Pandey, S. A Synthesis of 3Deoxydihydrolycoricidine: Refinement of a Structurally Minimum Pancratistatin Pharmacophore. Bioorg. Med. Chem. Lett. 2005, 15, 5315-5318.

(22) Pettit, G. R.; Tan, R.; Bao, G.-H.; Melody, N.; Doubek, D. L.; Gao, S.; Chapuis, J.-C.; Williams, L. Antineoplastic Agents. 587. Isolation and Structure of 3-Epipancratistatin From Narcissuscv. Ice Follies. J. Nat. Prod. 2012, 75, 771-773.

(23) Vshyvenko, S.; Scattolon, J.; Hudlicky, T.; Romero, A. E.; Kornienko, A. Synthesis of C-1 Homologues of Pancratistatin and Their Preliminary Biological Evaluation. Bioorg. Med. Chem. Lett. 2011, 21, 4750-4752.

(24) Vshyvenko, S.; Scattolon, J.; Hudlicky, T.; Romero, A. E.; Kornienko, A.; Ma, D.; Tuffley, I.; Pandey, S. Unnatural C-1 Homologues of Pancratistatin-Synthesis and Promising Biological Activities. Can. J. Chem. 2012, 90, 932-943.

(25) Vshyvenko, S.; Reisenauer, M. R.; Rogelj, S.; Hudlicky, T. Synthesis and biological evaluation of unnatural derivatives of 
narciclasine: 7- aza-narciclasine and its $\mathrm{N}$-oxide. Bioorg. Med. Chem. Lett. 2014, 24, 4236-4238.

(26) Vshyvenko, S.; W'Giorgis, Z.; Weber, A.; Neverova, N.; Hedberg, B.; Hudlicky, T. Synthesis and Biological Activity of 10-Azanarciclasine. Adv. Synth. Catal. 2015, 357, 83-87.

(27) Wang, P.; Li, L.-F.; Wang, Q.-Y.; Shang, L.-Q.; Shi, P.-Y.; Yin, Z. Anti-Dengue-Virus Activity and Structure-Activity Relationship Studies of Lycorine Derivatives. ChemMedChem 2014, 9, 1522-1533.

(28) Brown, C. E.; Kong, T.; McNulty, J.; D’Aiuto, L.; Williamson, K.; McClain, L.; Piazza, P.; Nimgaonkar, V. L. Discovery of Potent Antiviral (HSV-1) Quinazolinones and Initial Structure-Activity Relationship Studies. Bioorg. Med. Chem. Lett. 2017, 27, 4601-4605.

(29) McNulty, J.; Zepeda-Velázquez, C. Enantioselective Organocatalytic Michael/Aldol Sequence: Anticancer Natural Product (+)-Trans-Dihydrolycoricidine. Angew. Chem., Int. Ed. 2014, 53, $8450-8454$

(30) D’Aiuto, L.; Williamson, K.; Dimitrion, P.; McNulty, J.; Brown, C. E.; Dokuburra, C. B.; Nielsen, A. J.; Lin, W. J.; Piazza, P.; Schurdak, M. E.; Wood, J.; Yolken, R. H.; Kinchington, P. R.; Bloom, D. C.; Nimgaonkar, V. L. Comparison of Three Cell-Based Drug Screening Platforms for HSV-1 Infection. Antiviral Res. 2017, 142, 136-140. 